\title{
ANALISIS PROFIL KEMISKINAN MAKRO KABUPATEN MOJOKERTO
}

\author{
Gyska Indah Harya \\ gyskaharya.agribis@upnjatim.ac.id \\ Dosen pada Program Studi Agribisnis \\ Fakultas Pertanian \\ Universitas Pembangunan Nasional "Veteran" Jawa Timur
}

\begin{abstract}
ABSTRAK
Penelitian ini dengan judul Analisis Profil Kemiskinan Makro Kabupaten Mojokerto adalah untuk menyediakan data dan informasi kemiskinan makro di Kabupaten Mojokerto sampai dengan saat ini.

Tujuan dari penelitian ini antara lain: 1) menyajikan data terperinci mengenai situasi kemiskinan makro di Kabupaten Mojokerto dengan dalam bentuk naratif dan grafis yang berdasarkan data dari hasil publikasi BPS (Badan Pusat Statistik).

Hasil Penelitian ini antara lain : (1) Garis kemiskinan di Kabupaten Mojokerto untuk tahun 2018 adalah sebesar Rp. 370.610/kapita/ bulan dan termasuk dalam kategori rendah yaitu garis kemiskinan suatu wilayah Kabupaten/ Kota yang berada di bawah garis kemiskinan Provinsi maupun Nasional. (2) Jumlah penduduk miskin di Kabupaten Mojokerto pada tahun 2018, yaitu sebanyak 111.550 jiwa. Dengan demikian Kabupaten Mojokerto pada tahun 2018 hanya memberikan kontribusi sebesar 2,57 persen terhadap jumlah penduduk miskin di Provinsi Jawa Timur dan sebesar 0,43 persen pada jumlah penduduk miskin secara Nasional. (3) Posisi relatif jumlah penduduk miskin Kabupaten Mojokerto terhadap Kabupaten/Kota di Provinsi Jawa Timur pada tahun 2018 berada pada urutan ke 18 (delapan belas) dari yang terendah. (4) Perkembangan Jumlah penduduk miskin di Kabupaten Mojokerto selama tahun 2014-2018, menunjukkan perkembangan angka yang bersifat fluktuatif dengan trend perkembangan secara keseluruhan menunjukkan trend yang menurun. Penurunan jumlah penduduk miskin, dapat menjadi indikasi bahwa program-program pembangunan, utamanya yang berorientasi pada penanggulangan kemiskinan telah menunjukkan dampak positif dalam mengurangi angka penduduk miskin di Kabupaten Mojokerto.
\end{abstract}

\section{Kata kunci : Kabupaten Mojokerto, Kemiskinan Makro, Posisi Relatif.}

\section{PENDAHULUAN}

\section{Latar Belakang}

Kemiskinan masih menjadi salah satu persoalan mendasar yang menjadi pusat perhatian pemerintah di negara manapun, termasuk Indonesia. Kemiskinan merupakan gambaran kehidupan pada banyak negara ber-kembang yang mencakup lebih dari satu milyar penduduk dunia. Kemiskinan merupakan permasalahan yang dapat diakibatkan oleh kondisi nasional suatu negara dan situasi global. Menurut Kunarjo dalam Badrul Munir (2002:10), suatu negara dikatakan miskin biasanya ditandai dengan tingkat pendapatan perkapita rendah, mempunyai tingkat 
pertumbuhan penduduk yang tinggi (lebih dari 2 persen per tahun), sebagian besar tenaga kerja bergerak di sektor pertanian dan terbelenggu dalam lingkaran setan kemiskinan. Oleh karena itu permasalahan kemiskinan harus segera ditangani melalui implementasi langkah-langkah penanggulangan dan pendekatan yang terpadu, sistematis, dan menyeluruh.

Penanggulangan kemiskinan diarahkan untuk mengurangi beban rakyat miskin dan memenuhi hak-hak dasar warga negara secara layak melalui pembangunan inklusif, berkeadilan, dan berkelanjutan untuk mewujudkan kehidupan yang lebih bermartabat. Upaya penanggulangan kemiskinan akan dinyatakan efektif bila menun-jukkan Indikasi menurunnya jumlah penduduk miskin, bertambahnya tingkat pendapatan individu, dan menguatnya daya beli masyarakat. Keberhasilan upaya penanggulangan kemiskinan tidak dapat semata-mata ditentukan oleh hasil kerja satu sektor saja, tetapi sangat di-pengaruhi oleh hasil kerja keras serta kontribusi positif pelbagai sektor pembangunan lainnya. Semua kebijakan pembangunan bidang penang-gulangan kemiskinan yang sedang dan atau akan diselenggarakan hendaknya memiliki wawasan konprehensif, artinya semua program pembangunan penanggulangan kemiskinan harus memberikan kontribusi positif terhadap upayaupaya penanggulangan kemiskinan.

Untuk mewujudkan upaya-upaya penanggulangan kemiskinan di suatu wilayah sebagaimana diamanatkan oleh Permendagri nomor 42 tahun 2010, adalah dengan menyusun strategi penanggulangan kemiskinan. Di sisi lain Permendagri nomor 42 tahun 2010 juga mengamanatkan setiap daerah (Provinsi dan kabupaten/Kota) untuk menyusun laporan pelaksanaan penanggulangan kemiskinan. Salah satu hal yang yang paling dibutuhkan untuk menyusun strategi penanggulangan kemiskinan adalah profil kemiskinan itu sendiri. Sedangkan salah satu hal yang dapat digunakan untuk mengetahui pencapaian hasil kinerja upaya penanggulangan kemiskinan adalah juga profil kemiskinan terkini.

Profil kemiskinan adalah salah satu bentuk sistem infomasi kemisknan yang berupa gambaran umum tentang kondisi kemiskinan di suatu wilayah. Profil kemiskinan pada intinya berisi data/informasi yang akan memberikan menggambarkan kondisi kemiskinan, baik ditinjau dari sisi ekonomi maupun nonekonomi. Data/informasi kemiskinan dari sisi ekonomi menunjukkan data jumlah maupun persentase penduduk miskin berdasarkan garis kemiskinan di suatu wilayah. Juga memberikan gambaran informasi tentang kesenjangan informasi penduduk miskin terhadap garis kemiskinan maupun kesenjangan kemiskinan antar penduduk miskin.

\section{Maksud dan Tujuan Kegiatan}

Kegiatan penyusunan Profil Kemiskinan Makro Kabupaten Mojokerto tahun 2019 dimaksudkan untuk menyediakan data dan informasi kemskinan di Kabupaten Mojokerto sampai dengan saat ini.

Adapun tujuan penyusunan Profil Kemiskinan Makro di Kabupaten Mojokerto adalah: menyajikan data terperinci mengenai situasi kemiskinan makro di 
Kabupaten Mojokerto dengan dalam bentuk naratif dan grafis yang berdasarkan data dari hasil publikasi BPS (Badan Pusat Statistik).

\section{TINJAUAN PUSTAKA}

\section{Kemiskinan.}

Kemiskinan adalah ketidakmampuan seseorang atau sekelompok orang dari sisi ekonomi untuk memenuhi kebutuhan dasar makanan dan bukan makanan yang diukur dari sisi pengeluaran.

\section{Penduduk Miskin.}

Penduduk miskin adalah penduduk yang memiliki rata-rata pengeluaran per kapita per bulan di bawah Garis Kemiskinan. Penghitungan jumlah penduduk miskin di hitung dengan menggunakan pendekatan kebutuhan dasar yaitu besarnya rupiah yang dibutuhkan untuk dapat memenuhi kebutuhan dasar minimum (konsumsi minimum). Besaran rupiah tersebut untuk selanjutnya disebut dengan garis kemiskinan, yang merupakan kumpulan titik potong (cut off points) dari kelompok miskin dan tidak miskin.

\section{Garis Kemiskinan.}

Garis Kemiskinan (GK) terdiri dari dua komponen yaitu Garis Kemiskinan Makanan (GKM) dan Garis Kemiskinan Nonmakanan (GKNM).

\section{GK= GKM + GKNM}

Penghitungan Garis Kemiskinan dilakukan secara terpisah untuk daerah perkotaan dan perdesaan. Penduduk miskin adalah penduduk yang me-miliki rata-rata pengeluaran per kapita per bulan di bawah Garis Kemiskinan.

Teknik penghitungan Garis Kemiskinan, pada tahap pertama adalah menentukan penduduk referensi yaitu 20 persen penduduk yang berada di atas Garis Kemiskinan sementara, yang merupakan Garis Kemiskinan periode lalu yang diinflate dengan inflasi umum (IHK). Dari penduduk referensi ini kemudian dihitung Garis Kemiskinan Makanan (GKM) dan Garis Kemiskinan Non-Makanan (GKNM). Garis Kemiskinan Makanan (GKM) adalah jumlah nilai pengeluaran dari 52 komoditi dasar makanan yang riil dikonsumsi penduduk referensi yang kemudian disetarakan dengan 2.100 kilo kalori perkapita perhari. Penyetaraan nilai pengeluaran kebutuhan minimum makanan dilakukan dengan menghitung harga rata-rata kalori dari ke-52 komoditi tersebut. Selanjutnya GKM tersebut disetarakan dengan 2.100 kilo kalori dengan mengalikan 2.100 terhadap harga implisit rata-rata kalori.

Paket komoditi kebutuhan dasar makanan diwakili oleh 52 jenis komo-diti (padi-padian, umbi-umbian, ikan, daging, telur dan susu, sayuran, kacang-kacangan, buah-buahan, minyak dan lemak, dll). Ke 52 jenis komoditi ini merupakan komoditikomoditi yang paling banyak di kon-sumsi oleh orang miskin. Patokan ini mengacu pada hasil Widyakarya Pangan dan Gizi 1978.

Garis Kemiskinan Non-Makanan (GKNM) merupakan penjumlahan nilai kebutuhan minimum dari komoditi-komoditi non-makanan terpilih yang meliputi perumahan, sandang, pendidikan, dan kesehatan. Nilai kebu-tuhan minimum per 
komoditi/sub-kelompok non-makanan dihitung dengan menggunakan suatu rasio pengeluaran komoditi/sub-kelompok tersebut terhadap total pengeluaran komoditi/subkelompok yang tercatat dalam data Susenas modul konsumsi.

Rasio tersebut dihitung dari hasil Survei Paket Komoditi Kebutuhan Dasar 2004 (SPKKD 2004), yang dilakukan untuk mengumpulkan data penge-luaran konsumsi rumah tangga per komoditi nonmakanan yang lebih rinci dibandingkan data Susenas modul konsumsi.

Paket komoditi kebutuhan dasar non-makanan diwakili oleh 51 jenis komoditi di perkotaan dan 47 jenis komoditi di perdesaan. Garis Kemiskinan merupakan penjumlahan dari Garis Kemiskinan Makanan dan Garis Kemiskinan Non-Makanan. Penduduk yang memiliki rata-rata pengeluaran per kapita per bulan di bawah Garis Kemiskinan dikategori-kan sebagai penduduk miskin.

\section{Ukuran Kemiskinan.}

- Head Count Index (HCI-P0), yaitu persentase penduduk yang berada di bawah Garis Kemiskinan (GK).

- Indeks Kedalaman Kemiskinan (Poverty Gap Index - P1) adalah ukuran ratarata kesenjangan pengeluaran masing-masing pendu-duk miskin terhadap garis kemiskinan. Semakin tinggi nilai indeks, semakin jauh rata-rata pengeluaran penduduk dari garis kemiskinan.

- Indeks Keparahan Kemiskinan (Poverty Severity Index - P2) adalah ukuran yang memberikan gambaran mengenai penyebaran penge-luaran di antara penduduk miskin. Semakin tinggi nilai indeks, se-makin tinggi ketimpangan pengeluaran di antara penduduk miskin.

\section{Data Kemiskinan di Indonesia.}

Terdapat 2 (dua) jenis data kemiskinan, yaitu data kemiskinan makro dan data kemiskinan mikro. Kedua data tersebut memiliki perbedaan pada pendekatan penghitungannya dan tentunya berbeda pula pada kegunaan data.

Data kemiskinan makro merupakan data kemiskinan yang penghitungan-nya diperoleh melalui pendekatan makro yang didasarkan pada konsep kemampuan memenuhi kebutuhan dasar dengan pengumpulan data menggunakan data sampel bukan data sensus, sehingga hasilnya adalah estimasi (perkiraan). Sumber data yang digunakan adalah Survei Sosial Ekonomi Nasional (Susenas). Hasil penghitungan data kemiskinan melalui pendekatan makro (=data kemiskinan makro), hanya menunjukkan jumlah dan persentase penduduk miskin di setiap daerah ber-dasarkan estimasi. Data di level nasional merupakan penjumlahan pen-duduk miskin di seluruh provinsi. Data ini berguna untuk perencanaan dan evaluasi program kemiskinan dengan target geografis namun tidak dapat menunjukkan siapa dan dimana alamat penduduk miskin (sasaran) sehingga tidak operasional untuk program penyaluran bantuan langsung dan perlindungan sosial.

Data kemiskinan mikro merupakan data kemiskinan yang pengumpulan datanya diperoleh melalui sensus, bukan sampel. Kerena pengumpulan data dilakukan melalui sensus, maka diperoleh data tentang siapa dan dimana alamat penduduk 
miskin (sasaran) sehingga operasional untuk program penyaluran bantuan langsung dan perlindungan sosial. Pengumpulan data kemiskinan mikro didasarkan pada ciri-ciri/karakteristik rumah tangga miskin supaya pendataan bisa dilakukan secara cepat dan hemat biaya

\section{Ekonomi Daerah}

Untuk dapat memberikan gambaran kondisi ekonomi daerah adalah dengan melihat potensi unggulan daerah dan pertumbuhan ekonomi suatu daerah. Untuk mengetahui pertumbuhan ekonomi suatu daerah antara lain dapat diukur dengan melihat perkembangan Produk Domestik Regional Bruto (PDRB), tingkat pendapatan perkapita masyarakat serta pergeseran struktur perekonomian daerah, perluasan lapangan dan kesempatan kerja, serta perkembangan laju inflasi.

\section{Potensi Unggulan Daerah}

Selain dikenal sebagai salah satu tempat bersejarah karena terdapat tempat peninggalan sejarah kerajaan Majapahit yaitu di Kecamatan Trowulan, Kabupaten Mojokerto menyimpan banyak potensi unggulan yang menjanjikan peluang besar bagi masyarakat sekitar.

Potensi unggulan daerah yang berkembang di Kabupaten Mojokerto adalah sebagai berikut:

\section{a. Sektor industri.}

Pada sektor industri, berkembangnya kegiatan industri besar dan kecil/industri rumah tangga/kerajinan di Kabupaten Mojokerto telah membentuk kawasan tersendiri, antara lain:

- Industri besar: Ngoro Industri Persada (NIP), Industri Estate Mojokerto (di Kecamatan Mojoanyar) dan Industri Estate Jetis (di Kecamatan Jetis);

- Kecil/industri rumah tangga: Alas Kaki (Kecamatan Sooko, Trowulan dan Puri), Patung Batu (Kecamatan Trowulan), Cor Kuningan (Industri Kecamatan Trowulan), Gerabah (Kecamatan Puri), Kripik kedelai, ubijalar, ubikayu (kec. Gondang, Pacet).

Pengembangan kegiatan ekonomi tersebut didukung oleh pening-katan kapasitas produksi dan perluasan pangsa pasar dapat mem-berikan kontribusi yang signifikan bagi perkembangan Kabupaten Mojokerto.

\section{b. Sektor pariwisata.}

Kawasan paling strategis di Kabupaten Mojokerto adalah kawasan wisata. Banyaknya peninggalan sejarah kerajaan Mojopahit di Trowulan serta wisata alam dan buatan di Kecamatan Pacet dan Trawas.

- Seni Budaya: Grebeg Suro Mojopahit, Grebeg dan Haul Syeh Jumadil Kubro, Kesenian Bantengan, Tari Klasik, Mocopat, Karawitan.

- Wisata Alam: Pemandian Ubalan Pacet, Padusan Air Panas, Air Terjun Coban Canggu, Air Terjun Dlundung, Taman Hutan Rakyat R. Soeryo, Watu Blorok.

- Wisata Religi/Agama: Troloyo, Makam Syeh Jumadil Kubro, Makam Vihara, Makam Tirim, Makam Mendhek, Makam Krapyak. 
- Wisata Budaya/Peninggalan Majapahit: Petirtaan Jolotundo, Candi Bangkal, Candi Bajangratu, Candi Brahu, Candi Genting, Candi Wringinlawang, Candi Gentong, Candi Minakjinggo, Candi Jedong, Candi Kedaton, Candi Sumur Gantung, Candi Grinting, Candi Tikus, Candi Kasimantengah, Candi Siti Hinggil, Kolam Segaran.

Kawasan ini perlu didukung dengan penataan kios-kios suvenir, Pusat Informasi Pariwisata (PIP), penyediaan lokasi parkir dan pasar cinderamata yang mendukung obyek wisata sehingga akan men-jadikan Kabupaten Mojokerto menjadi semakin menarik untuk dikunjungi.

\section{c. Sektor tanaman pangan, perkebunan dan hortikultura.}

Di sektor tanaman pangan, perkebunan dan hortikultura ada dua komoditi utama yang dapat diandalkan menjadi produk komoditi perdagangan di skala regional Propinsi dan Nasional yaitu:

- Komoditi buah-buahan (mangga, alpukat, pisang, durian, sirsak, dll);

- Komoditi perkebunan (tebu, tembakau, mete, kayu putih dll), Padi, jagung, ubi jalar, ubi kayu, kedelai, kacang tanah, cabe rawit.

\section{Pertumbuhan Ekonomi}

Struktur ekonomi Kabupaten Mojokerto dapat diketahui dengan melihat perkembangan Produk Domestik Regional Bruto (PDRB) Kabupaten Mojokerto pada kurun waktu tertentu baik atas dasar harga berlaku maupun atas dasar harga konstan.

Laju pertumbuhan ekonomi Kabupaten Mojokerto tahun 2017 sebesar 5,74 persen, meningkat dibanding tahun sebelumnya yang mencapai 5,49 persen. Pertumbuhan ekonomi tertinggi dicapai oleh lapangan usaha Penyediaan Akomodasi dan Makan Minum sebesar 7,49 persen. Diikuti lapangan usaha Industri Pengolahan sebesar 6,68 persen; Informasi dan Komunikasi sebesar 6,67 persen; Transportasi dan Pergudangan sebesar 6,55 persen; dan Pengadaan Air, Pengelolaan Sampah, Limbah dan Daur Ulang sebesar 6,18 persen.

Lapangan usaha lainnya yang mengalami pertumbuhan dikisaran 5 persen adalah lapangan Perdagangan Besar dan Eceran, Reparasi Mobil dan Sepeda Motor sebesar 5,93 persen; Jasa Kesehatan dan Kegiatan Sosial sebesar 5,17 persen.

Lapangan usaha yang mengalami pertumbuhan paling rendah adalah sektor Pertanian, Kehutanan, dan Perikanan hanya sebesar 0,91 persen; dan Administrasi Pemerintahan, Pertahanan dan Jaminan Sosial Wajib sebesar 2,38 persen. Bila dibandingkan dengan pertumbuhan ekonomi di Provinsi Jawa Timur maupun Nasional, pertumbuhan ekonomi di Kabupaten Mojokerto untuk tahun 2018 lebih baik dibandingkan pertumbuhan ekonomi Provinsi Jawa Timur maupun Nasional.

\section{Perkembangan Inflasi}

Salah satu indikator perekonomian makro adalah angka inflasi di suatu daerah. Selama kurun waktu tahun 2013-2017 inflasi di Kabupaten Mojokerto ratarata 5,46 persen per tahun. Meskipun masih dalam kategori low inflation atau disebut juga inflasi satu digit, stabilitas perekonomian di Kabupaten Mojokerto sudah cukup bagus dengan rata-rata angka inflasinya tidak jauh dari 10 persen. 
Selama kurun waktu 2013-2017 perkembangan tingkat inflasi di Kabupaten Mojokerto memiliki kecenderungan yang menurun. Dengan perkembangan tingkat inflasi tersebut menunjukkan bahwa tingkat harga yang ter-jadi pada tahun 2017 jauh lebih baik dibandingkan dengan tahun-tahun sebelumnya. Dengan inflasi yang menúrun (membaik) secara tidak langsung akan memberi dampak bagi perkembangan kesejahteraan masyarakat Kabupaten Mojokerto.

\section{METODOLOGI}

\section{Jenis dan Sumber Data.}

Data yang akan digunakan dalam proses penyusunan Profil Kemiskinan berupa data-data sekunder yang akan di ambil dari instansi/lembaga terkait (pemerintah) yang berhubungan dengan kemiskinan maupun upaya-upaya penanggulangannya. Beberapa data sekunder yang digunakan (khususnya untuk kemiskinan makro) adalah data deret waktu (data time series) untuk kurun waktu minimal 5 tahun terakhir.

\section{Metode Analisa dan Penyajian Data.}

Data-data sekunder yang telah diperoleh agar dapat diinterpretasikan maka terlebih dahulu dilakukan analisa data menggunakan metode deskriptif dengan pendekatan analisis data sekunder.

Penyajian data sekunder dilakukan dalam bentuk:

- Bagan/grafik posisi relatif, bertujuan untuk membantu melihat kondisi data di tahun terakhir lebih tinggi, sama atau lebih rendah jika dibandingkan dengan kondisi data di tingkat Provinsi Jawa Timur dan Nasional.

- Bagan/grafik perkembangan antar waktu, untuk menjelaskan per-kembangan data dari waktu ke waktu (tahun ke tahun), apakah pencapaian data di tahun terakhir lebih tinggi, sama atau lebih rendah daripada pencapaian tahun-tahun sebelumnya, terutama dalam tiga hingga lima tahun terakhir. Selanjutnya menjelaskan apakah capaian indikator tersebut dari tahun ke tahun selama periode yang dimaksud mengalami fluktuasi, ataukah konsisten.

\section{HASIL DAN PEMBAHASAN}

\section{Profil Kemiskinan Makro Kabupaten Mojokerto}

Profil kemiskinan makro Kabupaten Mojokerto ini menguraikan tentang datadata makro kemiskinan dalam bentuk informasi naratif dan grafis yang bersumber dari hasil publiasi BPS (Badan Pusat Statistik).

\section{Garis Kemiskinan.}

Badan Pusat Statistik (BPS) mencatat bahwa Garis kemiskinan di Kabupaten Mojokerto untuk tahun 2018 adalah sebesar Rp. 370.610/kapita/ bulan, artinya angka tersebut merupakan batas minimum pendapatan yang harus dipenuhi untuk memperoleh standar hidup, baik untuk kebutuhan makanan dan non-makanan di Kabupaten Mojokerto. Jika di bawah angka tersebut maka masuk kategori penduduk 
miskin. Garis Kemiskinan (GK) tersebut terdiri dari GK makanan sekitar Rp 240.563/ kapita/bulan ditambah GK non-makanan lebih kurang Rp 130.047/ kapita/bulan.

Peranan komoditi makanan terhadap Garis Kemiskinan masih lebih besar dibandingkan peranan komoditi bukan makanan. Pada periode 2018 sumbangan Garis Kemiskinan Makanan terhadap Garis Kemiskinan sebesar 64,91 persen, kondisi ini tidak jauh berbeda dengan periode sebelumnya yaitu tahun 2017 yang sebesar 59,56 persen. Komoditi makanan yang berpengaruh besar terhadap nilai Garis Kemiskinan yaitu makanan minuman jadi, beras (padi-padian), serta tembakau dan sirih.

Diikuti kemudian dengan komoditi ikan, sayur-sayuran, serta telur dan susu. Sedangkan komoditi bukan makanan yang berpengaruh besar terhadap nilai Garis Kemiskinan yaitu biaya perumahan, serta aneka barang dan jasa. Perkembangan garis kemiskinan Kabupaten Mojokerto selama periode 5 tahun terakhir (tahun 2014-2018) adalah sebagaimana digambarkan pada grafik

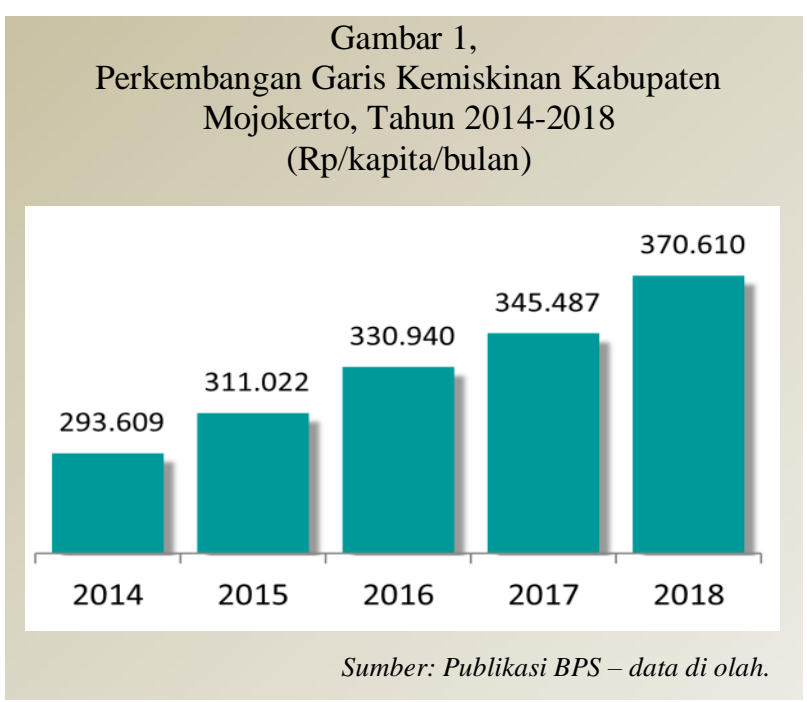
pada gambar 1 .

Pada grafik tersebut menunjukkan bahwa Garis Kemiskinan di Kabupaten Mojokerto selama kurun waktu tahun 2014-2018 terus meningkat. Dari tahun 2014 hingga tahun 2018 Garis Kemiskinan di Kabupaten Mojokerto naik sekitar Rp. 77.001, yaitu dari Rp. 293.609/kapita/bulan pada tahun 2014 menjadi Rp. 370.610/kapita/bulan pada tahun 2018.

Pada tahun 2018, Badan Pusat Statistik (BPS) mencatat bahwa Garis Kemiskinan Indonesia adalah sebesar Rp. 401.220/kapita/bulan, sedangkan Garis Kemiskinan di Provinsi Jawa Timur pada tahun yang sama adalah sebesar Rp. 373.547/kapita/bulan. Dengan demikian maka, posisi relatif garis kemiskinan Kabupaten Mojokerto pada tahun 2018, termasuk dalam kategori rendah yaitu garis kemiskinan suatu wilayah Kabupaten/ Kota yang berada di bawah garis kemiskinan Provinsi maupun Nasional. 


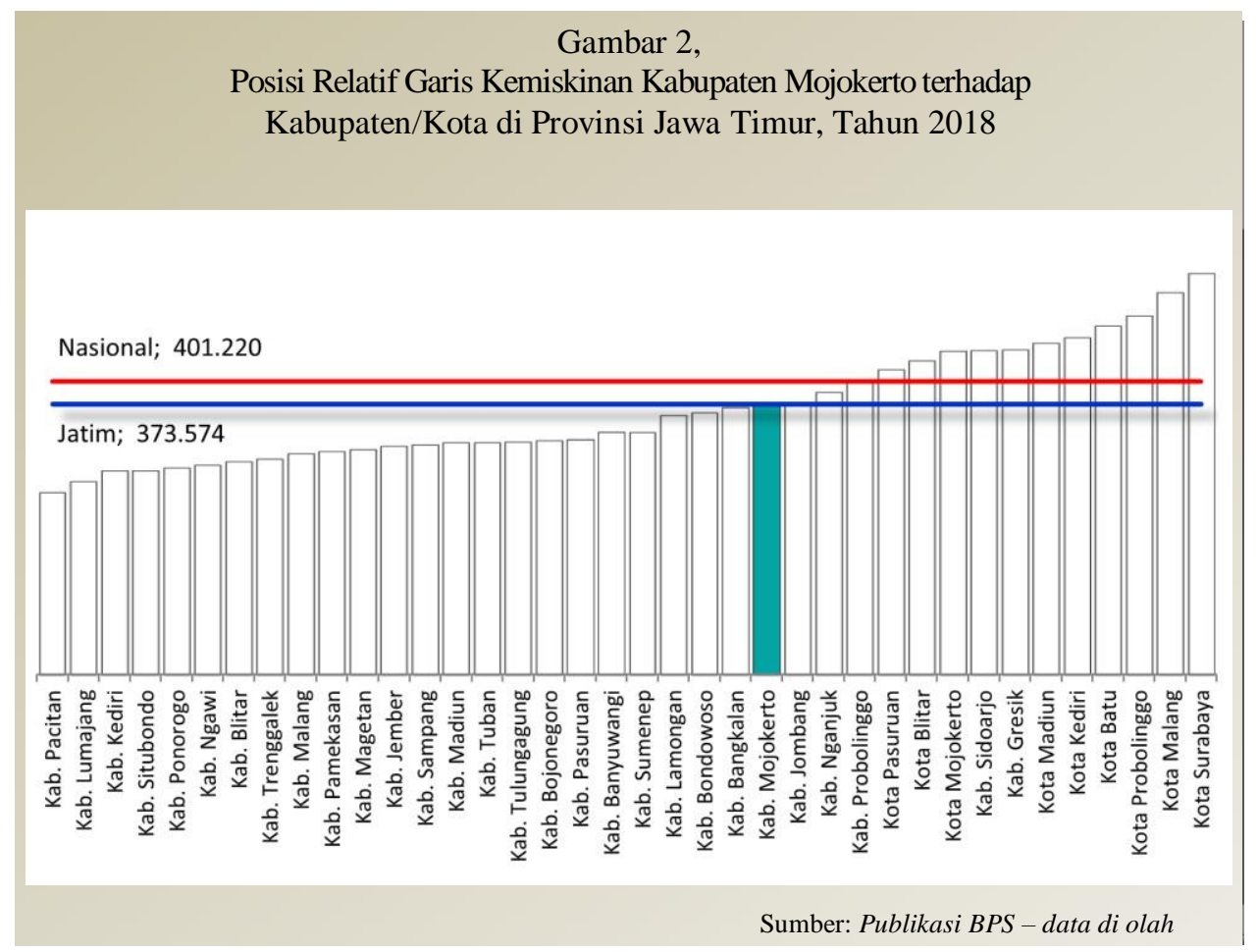

\section{Jumlah Penduduk Miskin}

Dengan menggunakan Garis Kemiskinan Kabupaten Mojokerto tahun 2018, maka Badan Pusat Statistik dapat menghitung (memperkirakan) jumlah penduduk miskin di Kabupaten Mojokerto pada tahun 2018, yaitu sebanyak 111.550 jiwa. Pada tahun yang sama, jumlah penduduk miskin di provinsi Jawa Timur sebesar 4.332.590 jiwa dan total penduduk miskin secara Nasional adalah sebesar 5.949.800 jiwa.

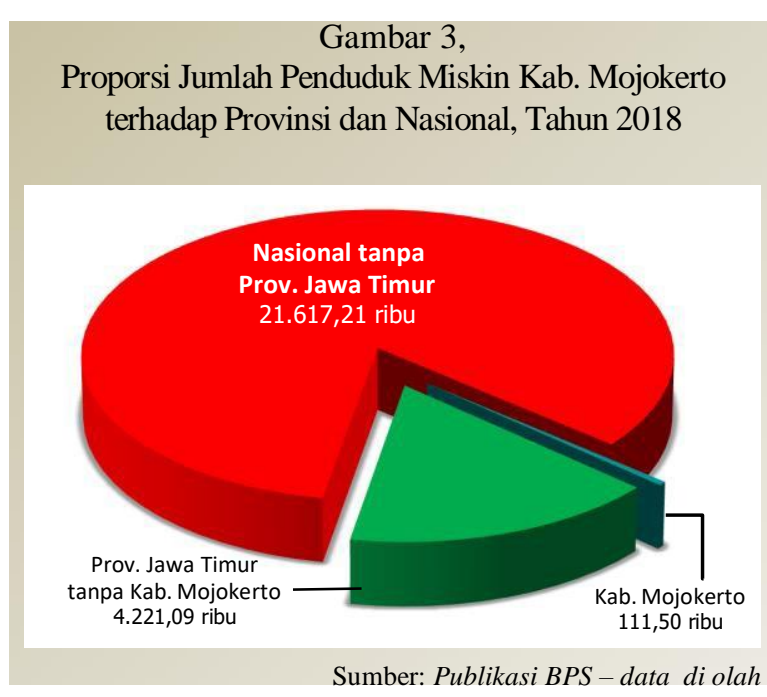

Dengan demikian Kabupaten Mojokerto pada tahun 2018 hanya memberikan kontribusi sebesar 2,57 persen terhadap jumlah penduduk miskin di Provinsi Jawa Timur dan sebesar 0,43 persen pada jumlah penduduk miskin secara Nasional.

Posisi relatif jumlah penduduk miskin Kabupaten Mojokerto terhadap Kabupaten/Kota di Provinsi Jawa Timur pada tahun 2018 berada pada urutan ke 18 (delapan belas) dari yang terendah. 


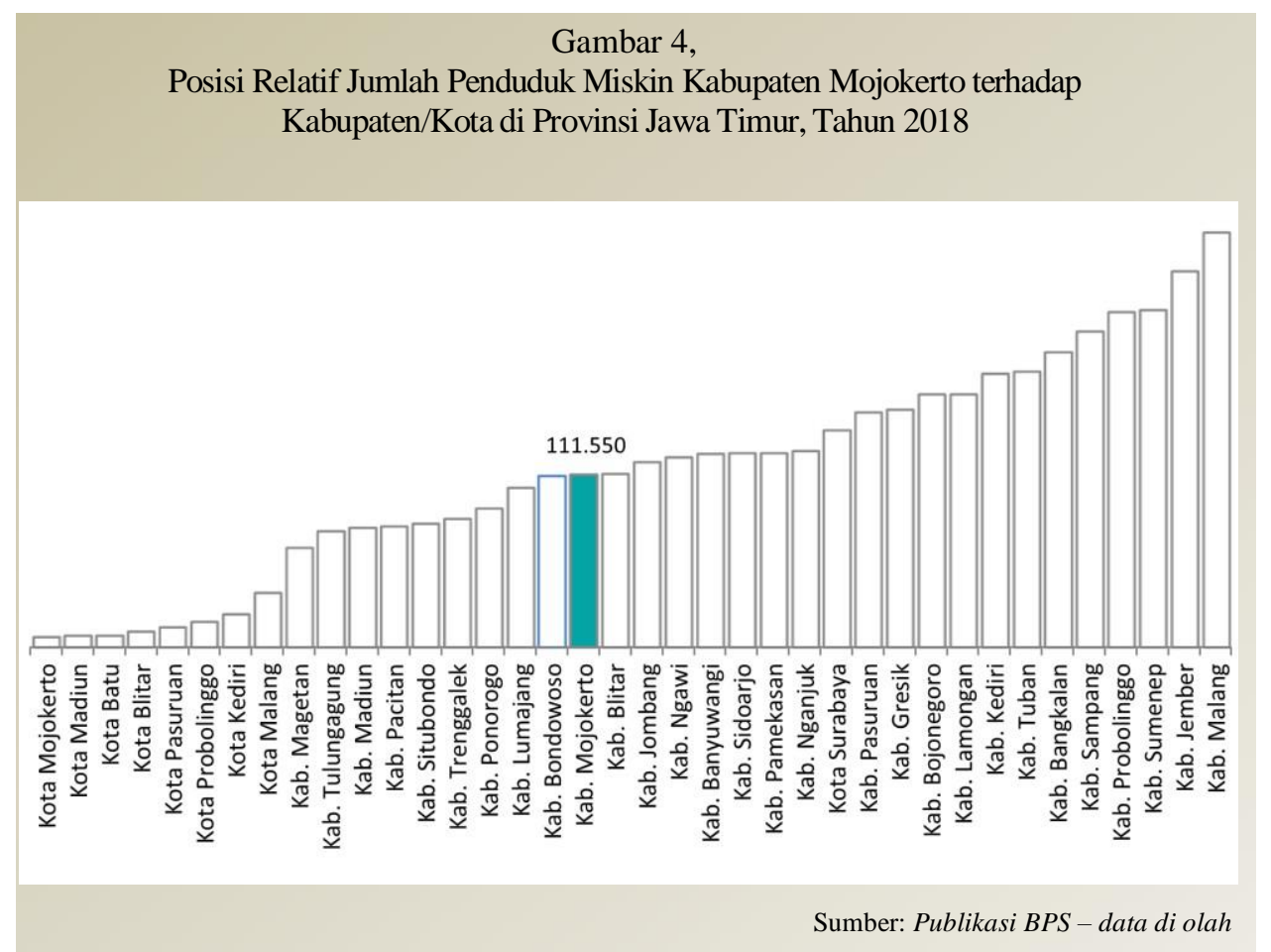

Perkembangan Jumlah penduduk miskin di Kabupaten Mojokerto selama

Gambar 5,

Perkembangan Jumlah Penduduk Miskin

Kabupaten Mojokerto, Tahun 2014-2018

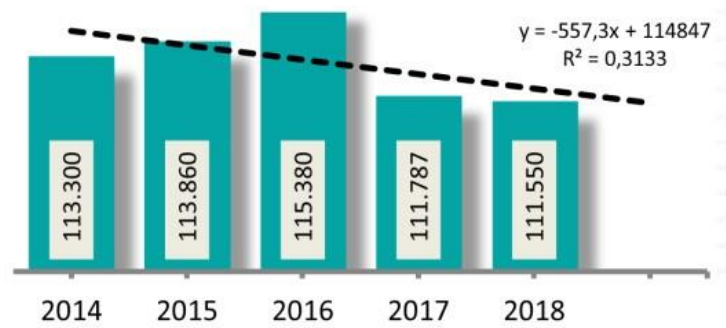

Sumber: Publikasi BPS - data di olah tahun 2014-2018, menunjukkan perkembangan angka yang bersifat fluktuatif dengan trend perkembangan secara keseluruhan menunjukkan trend yang menurun. Penurunan jumlah penduduk miskin, dapat menjadi indikasi bahwa program-program pembangunan, utamanya yang berorientasi pada penanggulangan kemiskinan telah menunjukkan dampak positif dalam mengurangi angka penduduk miskin di Kabupaten Mojokerto.

\section{Persentase Penduduk Miskin}

1) Posisi Relatif Persentase Penduduk Miskin Kabupaten Mojokerto terhadap Provinsi Jawa Timur dan Nasional. 
Persentase penduduk miskin di Kabupaten Mojokerto pada tahun 2018 adalah sebesar 10,08 persen. Bila melihat persentase penduduk miskin di Provinsi Jawa Timur maupun Nasional, di mana pada tahun yang sama persen-tase penduduk miskin di Provinsi Jawa Timur sebesar 10,85 persen sedangkan persentase penduduk miskin secara Nasional adalah sebesar 9,66 persen, maka persentase penduduk miskin Kabupaten Mojokerto berada pada

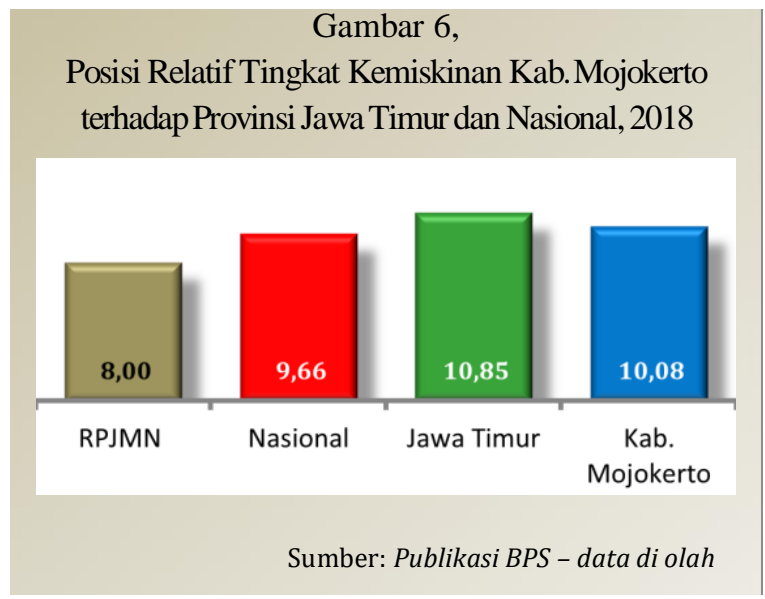
posisi sedang, karena meskipun masih sedikit lebih tinggi terhadap capaian secara Nasional, tetapi sudah berada di bawah capaian Provinsi Jawa Timur.

\section{2) Posisi Relatif Persentase Penduduk Miskin Kabupaten Mojokerto terhadap Kabupaten/Kota di Provinsi Jawa Timur.}

Diantara Kabupaten/Kota di Provinsi Jawa Timur, persentase penduduk miskin Kabupaten Mojokerto (pada tahun 2018) menempati posisi ke 18 (delapan belas) dari yang terendah.

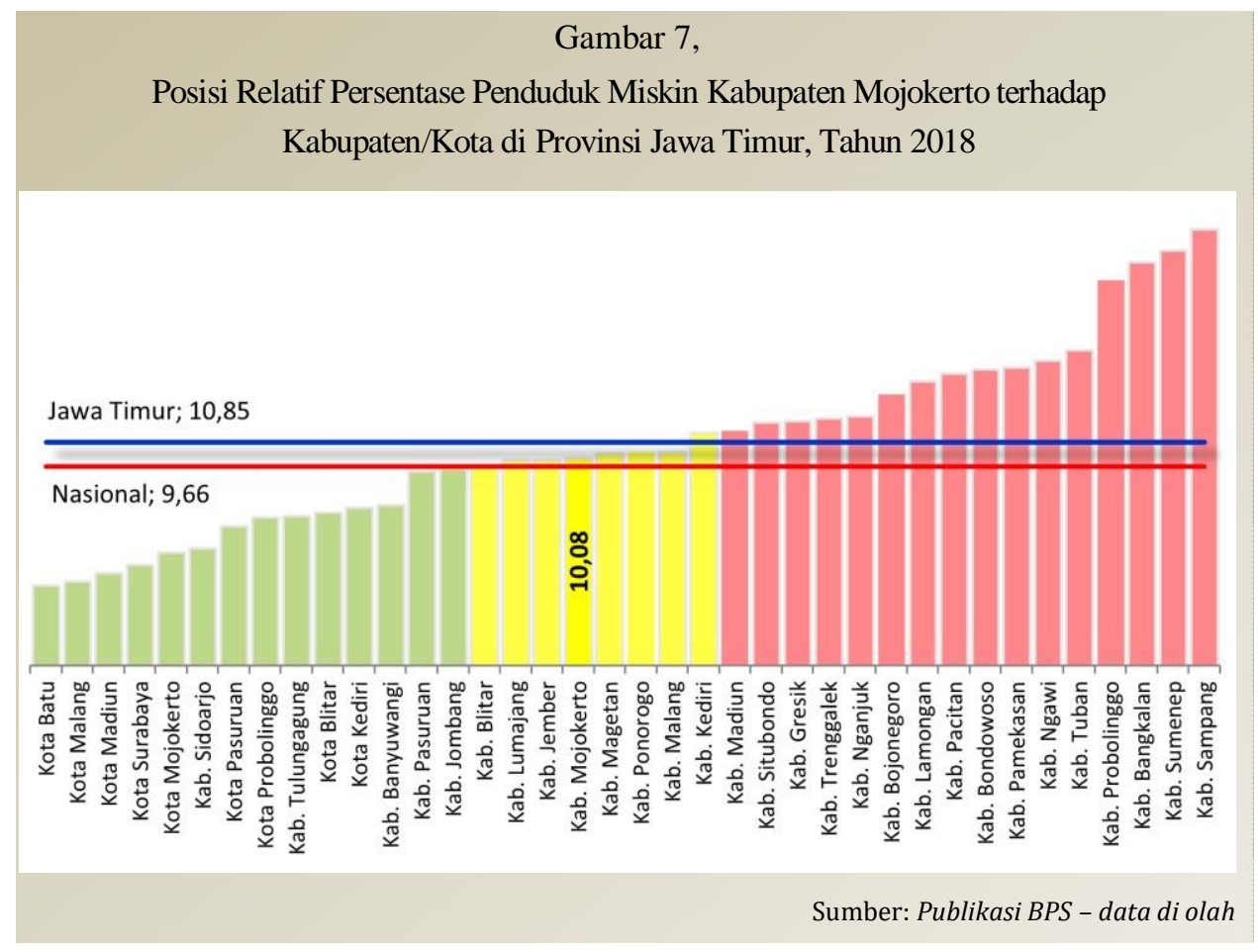

3) Perkembangan Persentase Penduduk Miskin Kab. Mojokerto. 


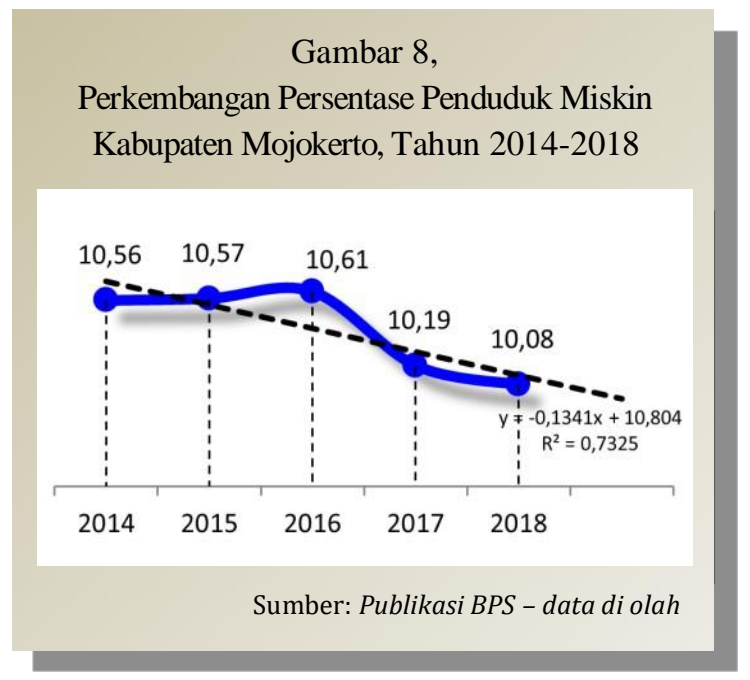

Capaian persentase penduduk miskin di Kabupaten Mojokerto selama periode tahun 2014-2018, menunjukkan perkembangan angka yang ber-sifat fluktuatif, dengan perkembangan capaian yang menunjukkan trend menurun. Rata-rata penurunan persentase penduduk miskin selama kurun waktu tersebut adalah sebesar $0,17 \%$ per-tahun. Perkembangan tingkat kemis-kinan yang menunjukkan trend menurun, dapat menjadi indi-kasi bahwa kebijakan dan program yang telah diupaya-kan oleh Pemerintah

Kabu-paten Mojokerto (khususnya pada 3 tahun terakhir) dalam rangka menurunkan persentase penduduk miskin dapat berjalan dengan efektif dan berdampak positif dalam mengurangi angka kemiskinan.

\section{4) Relevansi Perkembangan Persentase Penduduk Miskin Kabupaten Mojokerto terhadap Provinsi dan Nasional .}

Selama periode 2014-2018, trend perkembangan persentase penduduk miskin di Kabupaten Mojokerto menunjukkan trend yang sama (relevan) dengan trend perkembangan persentase penduduk miskin di Provinsi Jawa Timur mau-pun secara Nasional.

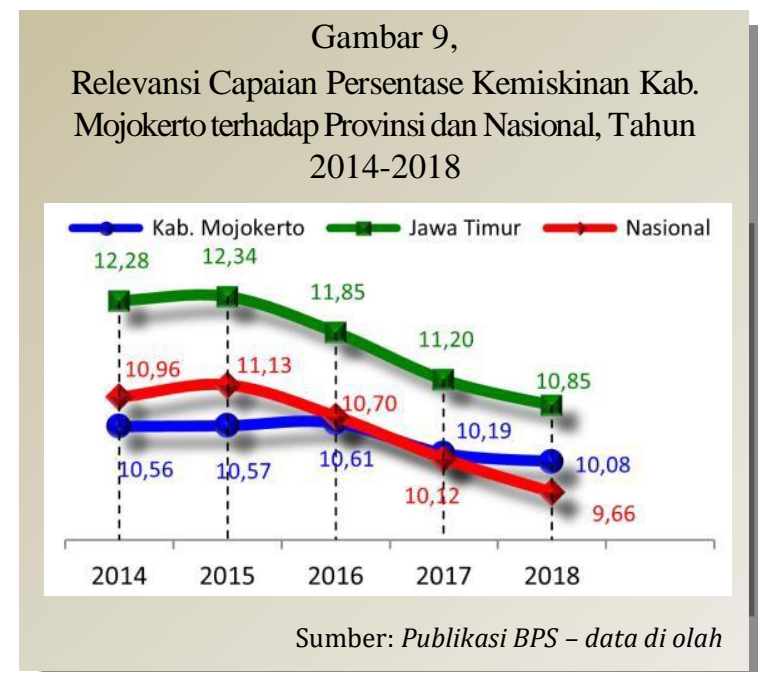

Meski menunjukkan trend yang
relevan, akan tetapi percepatan
penurunan angka kemiskinan di
Kabupaten Mojokerto hanya sekitar 34
persen dari rata-rata percepatan
penurunan angka kemiskinan di
Provinsi Jawa Timur dan sekitar 36
persen dari rata-rata percepatan
penurunan di tingkat Nasional.
Relevansi perkembangan
tingkat kemiskinan (persentase
penduduk miskin) antara Kabupaten
Mojokerto dengan Provinsi Jawa Timur
mau-pun Nasional dapat menjadi
indikasi bahwa upaya-upaya yang telah dilakukan Pemerintah Kabupaten Mojokerto dalam menurunkan tingkat kemiskinan melalui program dan kegiatan pembangunan telah sejalan dengan upaya-upaya di tingkat Provinsi Jawa Timur maupun Nasional.

\section{5) Posisi Kategori Perkembangan Persentase Kemiskinan Kabupaten Mojokerto.}




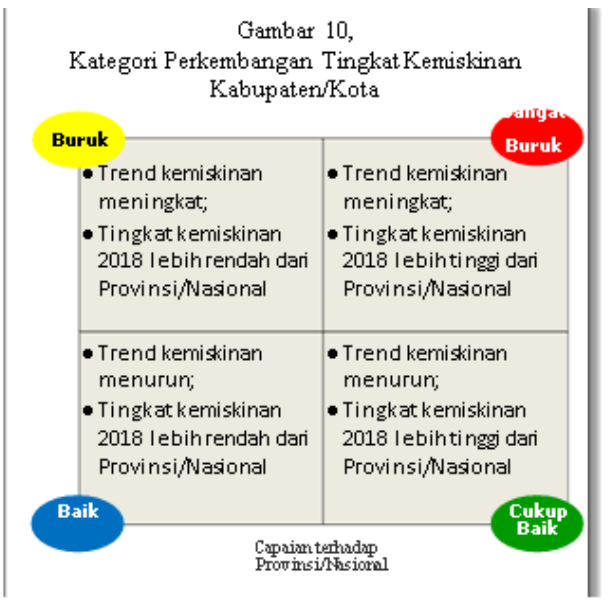

Berdasarkan pemahaman di atas, dengan status perkembangan tingkat kemiskinan Kabupaten Mojokerto untuk periode 5 (lima) tahun terakhir yang menurun dan posisi capaian tingkat kemiskinan Tahun 2018 ber-ada di bawah/lebih rendah dari capaian Provinsi Jawa Timur, maka Perkembangan Tingkat Kemiskinan Kabupaten Mojokerto di tingkat Provinsi Jawa Timur berada pada kategori baik.

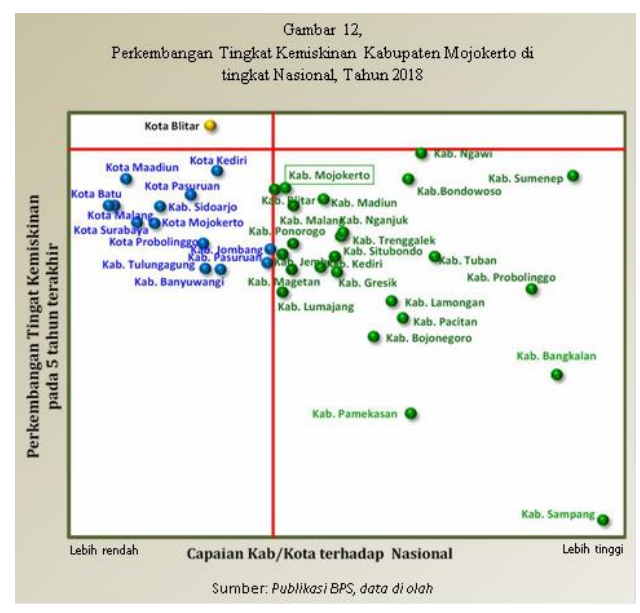
kartesius sebagai pembatas antara bidang yang menunjukkan trend meningkat dan trend menurun, dan capaian tingkat kemiskinan Provinsi Jawa Timur atau nasional menjadi sumbu y sebagai pembatas an-tara kondisi capaian di atas atau di bawah capaian Provinsi/Nasional, maka akan diperoleh posisi sebaran masing-masing Kabupaten/Kota pada 4 (empat) bidang kuadran kartesius.

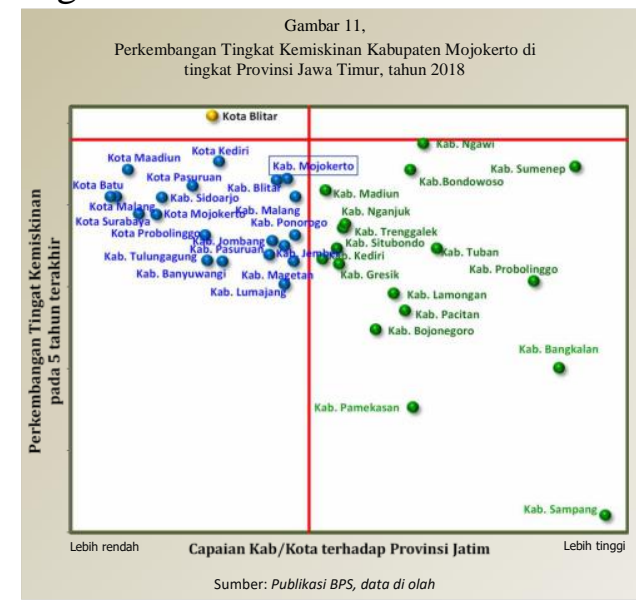

Sedangkan di tingkat Nasional, dengan status perkembangan tingkat kemiskinan Kabupaten Mojokerto untuk periode 5 (lima) tahun terakhir yang menurun dan posisi capaian tingkat kemiskinan Tahun 2018 berada di atas/lebih tinggi dari capaian Nasional, maka Perkembangan Tingkat Kemiskinan Kabupaten Mojokerto di tingkat Nasional berada pada kategori cukup baik.

Perkembangan Tingkat Kemiskinan (P0), Indeks Kedalaman Kemiskinan (P1), dan Indeks Keparahan Kemiskinan (P2).

Grafik berikut memberikan gambaran tentang perbandingan perkem-bangan Tingkat Kemiskinan/Persentase Penduduk Miskin (P0), Indeks Kedalaman Kemiskinan (P1), dan Indeks Keparahan Kemiskinan (P2) Kabupaten Mojokerto selama periode tahun 2014-2018.

- Persentase penduduk miskin pada tahun 2014 mencapai sekitar 10,56 persen, angka ini pada tahun 2018 turun sekitar 0,48 persen hingga menjadi sekitar 10,08 persen. Selama periode 2014-2018, penurunan rata-rata penduduk miskin pertahun sekitar 0,17 persen; 


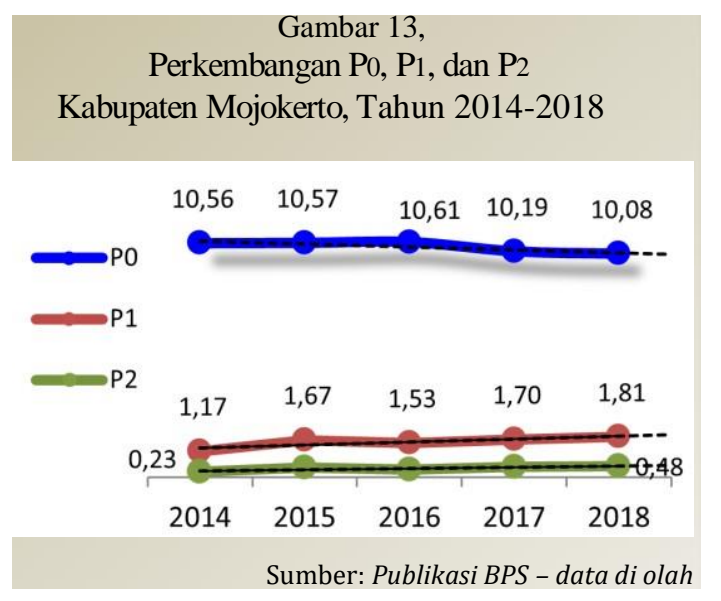

- Indeks kedalaman kemiskinan (P1) pada tahun 2014 mencapai sekitar 1,17 persen, angka ini pada tahun 2018 naik sekitar 0,64 persen hingga jadi sekitar 1,81 persen. Selama periode 2014-2018, peningkatan ratarata indeks kedalaman kemiskinan per-tahun sekitar 0,16 persen;

- Indeks keparahan kemiskinan (P2) pada tahun 2014 mencapai sekitar 0,23 persen, angka ini pada tahun 2018 naik sekitar 0,25 persen hingga jadi sekitar 0,48 persen. Selama periode 2014-2018, peningkatan rata-rata indeks keparahan kemiskinan per-tahun sekitar 0,06 persen;

Hal yang menarik dari data di atas adalah bahwa ternyata penurunan angka kemiskinan selama periode 2014-2018 tidak diikuti dengan penurunan Indeks kedalaman kemiskinan maupun indeks keparahan kemis-kinan. Juga bahwa pada tahun 2018 rata-rata pengeluaran dari 10,08 persen penduduk miskin semakin jauh dari garis kemiskinan, dan ketimpangan pengeluaran diantara penduduk miskin tersebut juga semakin tinggi.

\section{KESIMPULAN}

Berdasarkan hasil dan pembahasan sebelumnya dapat disimpulkan beberapa hal yang cukup penting diantaranya:

1. Garis kemiskinan di Kabupaten Mojokerto untuk tahun 2018 adalah sebesar Rp. 370.610/kapita/ bulan, Garis Kemiskinan (GK) tersebut terdiri dari GK makanan sekitar Rp 240.563/ kapita/bulan ditambah GK non-makanan lebih kurang Rp 130.047/ kapita/bulan.

2. Pada tahun 2018, Badan Pusat Statistik (BPS) mencatat bahwa Garis Kemiskinan Indonesia adalah sebesar Rp. 401.220/kapita/bulan, sedangkan Garis Kemiskinan di Provinsi Jawa Timur pada tahun yang sama adalah sebesar Rp. 373.547/kapita/bulan. Dengan demikian maka, posisi relatif garis kemiskinan Kabupaten Mojokerto pada tahun 2018, termasuk dalam kategori rendah yaitu garis kemiskinan suatu wilayah Kabupaten/ Kota yang berada di bawah garis kemiskinan Provinsi maupun Nasional.

3. Jumlah penduduk miskin di Kabupaten Mojokerto pada tahun 2018, yaitu sebanyak 111.550 jiwa. Pada tahun yang sama, jumlah penduduk miskin di provinsi Jawa Timur sebesar 4.332.590 jiwa dan total penduduk miskin secara Nasional adalah sebesar 5.949.800 jiwa. Dengan demikian Kabupaten Mojokerto pada tahun 2018 hanya memberikan kontribusi sebesar 2,57 persen terhadap jumlah penduduk miskin di Provinsi Jawa Timur dan sebesar 0,43 persen pada jumlah penduduk miskin secara Nasional. 
4. Posisi relatif jumlah penduduk miskin Kabupaten Mojokerto terhadap Kabupaten/Kota di Provinsi Jawa Timur pada tahun 2018 berada pada urutan ke 18 (delapan belas) dari yang terendah.

5. Perkembangan Jumlah penduduk miskin di Kabupaten Mojokerto selama tahun 2014-2018, menunjukkan perkembangan angka yang bersifat fluktuatif dengan trend perkembangan secara keseluruhan menunjukkan trend yang menurun. Penurunan jumlah penduduk miskin, dapat menjadi indikasi bahwa programprogram pembangunan, utamanya yang berorientasi pada pe-nanggulangan kemiskinan telah menunjukkan dampak positif dalam mengurangi angka penduduk miskin di Kabupaten Mojokerto.

Profil Kemiskinan Makro Kabupaten Mojokerto Tahun 2019 ini diharapkan dapat memberikan gambaran informasi tentang berbagai kondisi data kemiskinan di Kabupaten Mojokerto yang berupa data makro. Data ini dapat digunakan sebagai salah satu indikator capaian kinerja dalam penyelenggaraan pemerintahan di lingkungan Perangkat Daerah Kabupaten Mojokerto sebagai wujud transparansi dan akuntabilitas dalam melaksanakan urusan yang menjadi kewenangan dan ketugasan.

Sumber utama data makro adalah dari publikasi BPS (Badan Pusat Statistik) baik di Kabupaten Mojokerto sendiri, maupun data yang dipublikasikan oleh BPS Provinsi Jawa Timur dan BPS Pusat. Selain itu juga di dukung dengan data dari Perangkat Daerah terkait di Kabupaten Mojokerto. Data-data ini diharapkan dapat bermanfaat untuk perencanaan program dankegiatan serta menjadi bahan evaluasi pelaksanaan program dan kegiatan penangulangan kemiskinan di Kabupaten Mojokerto.

Disamping itu, ketersediaan data dan informasi dari Profil Kemiskinan Kabupaten Mojokerto ini diharapkan juga bermanfaat bagi pihak eksternal untuk memenuhi kebutuhannya dan dengan harapan penyusunan data pada Profil Kemiskinan Makro Kabupaten Mojokerto inipun dapat sesuai dengan tugas dan kewenangannya masing-masing.

\section{DAFTAR PUSTAKA}

Badan Perencanaan Pembangunan Daerah Kabupaten Mojokerto. 2013. Buku Pemetaan Kemisknan Kabupaten Mojokerto 2013. Mojokerto.

Badan Pusat Statistik. 2011. Ensiklopedia Indikator Ekonomi dan Sosial. Jakarta.

Badan Pusat Statistik. 2015. Data dan Informasi Kemiskinan Kabupaten/Kota Tahun 2014. Jakarta.

Badan Pusat Statistik. 2016. Data dan Informasi Kemiskinan Kabupaten/Kota Tahun 2015. Jakarta.

Badan Pusat Statistik. 2017. Data dan Informasi Kemiskinan Kabupaten/Kota Tahun 2016. Jakarta. 
Badan Pusat Statistik. 2018. Data dan Informasi Kemiskinan Kabupaten/Kota Tahun 2017. Jakarta.

Badan Pusat Statistik. 2019. Data dan Informasi Kemiskinan Kabupaten/Kota Tahun 2018. Jakarta.

Badan Pusat Statistik Kabupaten Mojokerto. 2017. Kabupaten Mojokerto Dalam Angka Tahun 2017. Mojokerto.

Badan Pusat Statistik Kabupaten Mojokerto. 2018. Kabupaten Mojokerto Dalam Angka Tahun 2018. Mojokerto.

Badan Pusat Statistik Kabupaten Mojokerto. 2018. Produk Domestik Regional Bruto Kabupaten Mojokerto menurut Lapangan Usaha Tahun 2013-2017. Mojokerto.

Badan Pusat Statistik Kabupaten Mojokerto. 2018. Produk Domestik Regional Bruto Kabupaten Mojokerto menurut Pengeluaran Tahun 2013-2017. Mojokerto.

Badan Pusat Statistik Provinsi Jawa Timur. 2018. Produk Domestik Regional Bruto Kabupaten/Kota di Provinsi Jawa Timur menurut Lapangan Usaha Tahun 20132017. Surabaya.

Badan Pusat Statistik Provinsi Jawa Timur. 2018. Produk Domestik Regional Bruto Kabupaten/Kota di Provinsi Jawa Timur menurut Pengeluaran Tahun 20132017. Surabaya.

Kadji, Yulianto, Tt. Kemiskinan dan Konsep Teoritisnya. dalam repository.ung. ac.id. diakses pada 15 April 2019.

Kartasasmita, Ginanjar. 1996. Pembangunan Untuk Rakyat, Memadukan Pertumbuhan dan Pemerataan. Jakarta : Pustaka Cidessindo.

Kementerian Perencanaan Pembangunan Nasional/Badan Perencanaan Pembangunan Nasional. 2010. Buku III - Alat Analisis Tepat Guna untuk Perencanaan dan Penganggaran yang Berpihak pada Masyarakat Miskin. Jakarta.

Kurnianingsih, T. 2006. Diimensi Kemiskinan. Jakarta : Biro Analisa Anggaran dan Pelaksanaan APBN-Setjen DPR RI.

Nasikun. 2001. Isu dan Kebijakan Penanggulangan Kemiskinan. Yogyakarta.

Sugiyono. 2010. Metode Penelitian Kuantitatif Kualitatif \& RND. Bandung : Alfabeta. 
Tim Nasional Percepatan Penanggulangan Kemiskinan (TNP2K). 2010. Panduan Praktis Analisis Data untuk Mendukung Koordinasi Penanggulangan Kemiskinan. Jakarta

Tim Nasional Percepatan Penanggulangan Kemiskinan (TNP2K). 2011. Panduan Penanggulangan Kemiskinan - Buku Pegangan Resmi TKPK Daerah. cetakan kedua. Mei 2011. Jakarta.

------, 2013. Profil dan Analisis Kemiskinan Nasional 2013.

------, Rancangan Akhir Perubahan RPJMD Kabupaten Mojokerto tahun 2016-2021.

------, http://bdt.tnp2k.go.id/

------, http://bps.go.id/

------, http://jatim.bps.go.id/

------, http://mojokertokab.bps.go.id/

------, http://www.tnp2k.go.id/ 